\title{
Water Quality Assessment of Sukhna Lake of Chandigarh City of India
}

\author{
P. Chaudhry, M.P. Sharma, R. Bhargave,
}

S. Kumar and P.J.S.Dadhwal
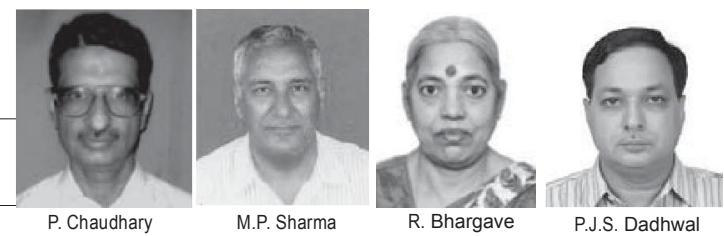

\begin{abstract}
The Sukhna Lake of Chandigarh City is a man-made lake situated in the foothills of the Shivalik range in the north-east corner of the city. This urban lake is one of the prime tourist places of the 'City Beautiful' and is mainly used for recreational purposes like boating, morning and evening strolls, exercises, food plaza and sightseeing. The catchment of the lake is mainly hilly and erosion prone, with the Sukhna wildlife sanctuary comprising a major portion of it. The water quality index of the lake water and its dependence on catchment characteristics has been studied. By using the National Sanitation Foundation Water Quality Index (NSFWQI) and Overall Index of Pollution (OIP), the results of the water quality assessment have found the lake water as having 'good' and 'acceptable' quality respectively based on past seven years' data. During the last few years, construction activities in the catchment area have speeded up and a few invasive alien plant species have come up in the lake. Inflow of untreated domestic waste water from nearby villages in the catchment, particularly during the rainy season, seems to be the main reason for the weed problem in the lake. Strict enforcement of ban on new construction activities and preventing the release of untreated domestic waste water from the villages located in the catchment are the absolute necessary steps for maintaining and improving the lake water quality.
\end{abstract}

Key words: Lake catchment characteristics, market and non-market benefits, Shivalik hills, water quality index, water quality parameters, India

\section{Introduction}

The lakes, rivers and wetlands provide a number 1 of environmental, social and educational benefits to mankind. The quality and quantity of these resources is an indicator of sustainable development of a country. Water bodies like lakes and rivers located in urban cities provide market and non-market benefits like boating, recreation, nature viewing, climate amelioration, water flow regulation, carbon sequestration etc. The world scientific community is presently unanimous about such non-market/intangible benefits provided by lakes/ rivers/wetlands. Efforts were made by Costanza, d'Arge et al (1997) to quantify and value the benefits provided by natural capital like oceans, forests, grasslands, wetlands and lakes/rivers. It was found that non-market services in the form of water regulation, water supply, waste treatment and recreational aspects constitute the major portion of overall benefits/services provided by lakes/ rivers.

A lake is the most beautiful and expressive feature of a landscape. In India, there are relatively few natural lakes in the Himalaya region and in the floodplains of the Indus, Ganga and Brahamaputra. A number of artificial water bodies were constructed during the last 1,000 years in western and peninsular India (Gopal, Sengupta et al 2010). Lakes are classified on the basis of the salinity level of water like freshwater, brackish or saline lakes. On the basis of their nutrient content, these are also categorized as Oligotrophic (low nutrients), Mesotrophic (medium nutrients), and Eutrophic (high nutrients) lakes. The vast majority of lakes in India are either Eutrophic or Mesotrophic on account of receiving nutrients from their catchments. Literature reveals that a number of studies have been conducted in India on water quality assessment of water bodies like Halai, Koloroi, Kalyani, Salim Ali, Dahi-Khura, Ramgarh,
Kalakho and Dalvoy Lake (Jain, Sharma and Thakur 1996; Sreenivasan Venkatanarasimha and Franklin 1997; Srinivasa and Kotaiah 2000; Thorat and Masaraat 2000; Shastri and Pendse, 2001; Moundiotiya, Sisodia et al 2004; Sisodia and Moundiotiya 2006; Mahesha and Balasubramanian 2010). Padmanabha and Belagali (2005) monitored the water quality of four lakes in Mysore city during November 2004 to April 2005. Based on pH, total alkalinity, total hardness, chloride, calcium, magnesium, total dissolved solids, dissolved oxygen and BOD, it was found that the water of these lakes was severely polluted and unfit for human consumption. Mahesha and Balasubramanian (2010) found the Dalvoy Lake of Mysore city as having poor water quality. Sisodia and Moundiotiya (2006) found that the Kalakho Lake of Rajasthan has poor water quality due to lack of proper sanitation, flow of untreated municipal sewage and agricultural runoffs. In both cases, the lake water was found unfit for drinking and propagation of wild life and fish culture. Further, Moundiotiya, Sisodia et al (2004) studied the physicochemical parameters of the Jamwa Ramgarh wetland and advocated habitat conservation and ecological restoration as the measures to prevent the wetland from becoming ecologically inactive.

The present paper deals with the water quality assessment of the Sukhna Lake of Chandigarh City of India and its pollutional status. The Chandigarh administration is already undertaking suitable conservation measures to maintain its recreational and aesthetic status for the residents of the city and tourists coming to the city. This Lake of Chandigarh City has the potential of providing tangible and intangible benefits to the people of the region, though no scientific study has yet been reported on this aspect of the lake. Suggestive conservation measures are also covered in the paper. 


\section{About the Sukhna Lake}

The Sukhna Lake was created artificially in 1958 by constructing an earthen dam of about $3 \mathrm{kms}$ length and $14 \mathrm{~m}$ height on the Sukhna choe (seasonal rivulet). The lake is located in the north east corner of Chandigarh City; the location map is given in Figure 1. Presently, the lake is fed mainly by two hilly torrents, the Kansal and Nepli choes. Total catchment area of the lake is about 42 $\mathrm{km}^{2}$, of which $33 \mathrm{~km}^{2}$ falls in the Shivalik hills and rest in a few villages of Punjab, Haryana and Union Territory (UT) of Chandigarh. The width of the top dam is $23 \mathrm{~m}$ and the length of walk way is about $3 \mathrm{~km}$.

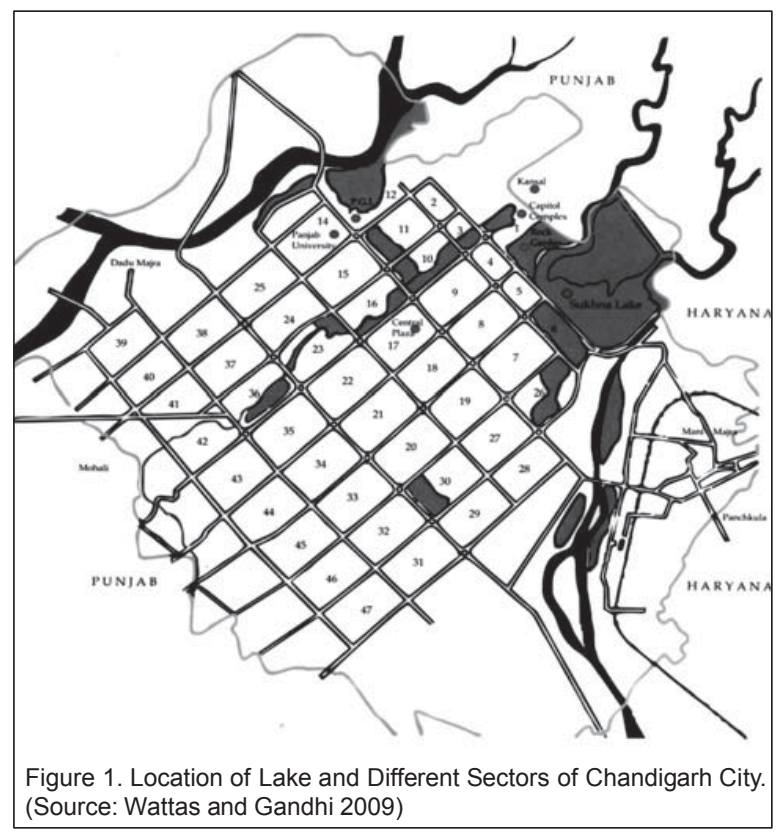

The lake is the main tourist attraction for Indian and foreign tourists. About 1,000 to 1,500 tourists visit the lake on weekdays and 2,500 to 3,000 on weekends for boating. The Chandigarh Industrial and Tourism Development Corporation (CITCO), which looks after boating arrangements in the lake, is generating between IRs. 60,000 to $70,000 /-$ per day from boating. Residents of the city, irrespective of age, use the lake site for morning/evening walks and recreational purposes. Chandigarh city has some famous tourist spots like Nek Chand's Rock Garden, Zakir Rose Garden, Leisure Valley, Bougainvillea Garden etc., but the Sukhna Lake is considered as the top most tourist spot by the people of the city (Chaudhry, Singh and Tewari 2007). Apart from this, three Asian and six National level rowing competitions were organized at the lake during the last three decades. A large number of winged guests from Siberia and other European countries are also visiting the lake, particularly during the winter season, when the lake has sufficient water. These migratory birds include Coots, Pochards, Mallards, Geese, Eagrets, Teals, Herons, Ducks etc. but lower rainfall during the last few years and detrimental catchment activities have resulted in accumulation of silt and excessive growth of weed indicating the onset of the eutrophication process in the lake.

\section{Characteristics of Lake Catchment}

The climate of the area is semi-arid with a maximum mean temperature of $41.80^{\circ} \mathrm{C}$ in June and minimum temperature of $5.10^{\circ} \mathrm{C}$ in January. Average annual rainfall is $1,120 \mathrm{~mm}, 80 \%$ of which is received during the monsoon season from July to September. The Shivalik foot-hills are one of the seven most degraded ecosystems of India. These low hills of recent origin are made up of one of the most erodible soils of the world. In the last 400 years, the vegetative cover of the hills has been destroyed by human activities resulting in significant mass soil erosion in the monsoon period. Low productivity, poor vegetative cover, high runoffs, soil loss and presence of deep and wide network of gullies are the main characteristics in the upper catchment of the lake. All these factors are responsible for the heavy siltation of the Sukhna Lake (SPACE 2008). Different parent material, namely sand stone and shale occur side by side, their differential hydrothermal properties and erosional behavior give rise to lack of cohesion causing heavy runoffs from the bare hill slopes (Grewal and Juneja 1984).

\section{Types of Vegetation}

There are wide varieties of trees, shrubs, herbs, grasses and climbers in the catchment. The prominent tree species in the catchment area include Khair (Acacia catechu), Kikar (Acacia nilotica), Shisham (Dalbergia sissoo), Eucalyptus species and Muscat (Prosopis juliflora). The Sukhna wildlife sanctuary is also rich in other tree species like Chhal (Anogeissus latifolia), Neem (Azadirachta indica), Semal (Bombax ceiba), Dhak (Butea frondosa), Kachnar (Bauhinia racemosa), Amla (Emblica officinalis), Tut (Morus alba) Amaltas (Cassia fistula) etc. The overall tree density is around 500 trees per ha in the sanctuary area. Important shrubs in the area include Basuti (Adatoda vasica), Lantana (Lantana camara), Karipatta (Murraya koenigii), Beri (Zizyphus mauritiana) and Karonda (Carissa spinarum). During 2002-08, the Forest Department removed Lantana from the sanctuary area as it is an aggressive Invasive Alien Species (IAS) and does not allow other favorable species to come up nearby. Considerable success has been achieved as evidence from the natural regeneration of favorable species in the sanctuary.

\section{Water Quality Status of the Lake}

For the purpose of continuous monitoring of lake water quality, water samples were collected from the centre of the lake using local boats by the 'Pollution Control Committee' of the Chandigarh administration once every month from the year 2006-2012. The monthly data were averaged to get the annual data as reported in Table 1. The analysis of samples for water quality parameters was carried out as per standard methods of 


\begin{tabular}{|c|c|c|c|c|c|c|c|c|}
\hline Parameters & Unit & 2006 & 2007 & 2008 & 2009 & 2010 & 2011 & 2012 \\
\hline Temperature & ${ }^{\circ} \mathrm{C}$ & 26 & 27 & 25 & 24 & 26 & 25 & 25 \\
\hline $\mathrm{pH}$ & Std unit & 7.6 & 8.1 & 8.0 & 7.9 & 7.4 & 7.4 & 8.1 \\
\hline Turbidity & NTU & 88 & 80 & 64 & 92 & 95 & 44 & 42 \\
\hline TS & $\mathrm{mg} / \mathrm{l}$ & 381 & 262 & 270 & 267 & 136 & 173 & 218 \\
\hline DO & $\mathrm{mg} / \mathrm{l}$ & 8.1 & 6.4 & 6.9 & 7.9 & 7.0 & 10.3 & 6.8 \\
\hline BOD & $\mathrm{mg} / \mathrm{l}$ & 2.5 & 1.6 & 1.4 & 2.0 & 2.5 & 2.0 & 3.0 \\
\hline TP & $\mathrm{mg} / \mathrm{l}$ & 0.4 & $\mathrm{BDL}^{*}$ & $\mathrm{BDL}^{*}$ & 0.05 & 0.16 & $\mathrm{BDL}^{*}$ & 0.6 \\
\hline Nitrate & $\mathrm{mg} / \mathrm{l}$ & 3.25 & $\mathrm{BDL}^{*}$ & 1.32 & $\mathrm{BDL}^{*}$ & 0.59 & 0.04 & 0.16 \\
\hline NSFWQI & & 72 & 73 & 76 & 79 & 76 & 85 & 77 \\
\hline \multicolumn{2}{|c|}{ Water quality as per NSFWQI } & Good & Good & Good & Good & Good & Good & Good \\
\hline \multicolumn{2}{|c|}{ OIP } & 1.71 & 1.66 & 1.50 & 1.66 & 1.80 & 1.25 & 1.58 \\
\hline \multicolumn{2}{|c|}{ Water quality as per OIP } & Acceptable & Acceptable & Acceptable & Acceptable & Acceptable & Acceptable & Acceptable \\
\hline
\end{tabular}

Table 1. Water Quality Parameters of Lake Water (Annual Average).

$\mathrm{BDL}^{*}$ - Beyond Detectable Limit

analysis (APHA 1989).

Water quality assessment is a tool that provides valuable information for the policy and decision makers. The Water Quality Index (WQI) is a single number that expresses the overall water quality at a certain location and turns complex water quality data into information that is understandable and usable by the general public. It is one of the most effective tools to communicate information on the quality of water to the concerned citizens and policy makers. Horton (1965) proposed the first WQI followed by other indices including National Sanitation Foundation (NSF) of USA which is accepted as a more convenient WQI based on expert or panelist's opinion (Brown, McClelland et al 1970). Besides the National Sanitation Foundation Water Quality Index (NSFWQI), some other water quality indices used worldwide in practice include the Canadian Council of Ministers of the Environment Water Quality Index (CCMEWQI) (Lumb 2006), British Columbia Water Quality Index (BCWQI) and Oregon Water Quality Index (OWQI) (Debels, Figueroa et al 2005; Kannel, Lee et al 2007; Abbasi 2002). In the Indian context, Sargaonkar and Deshpande (2003) developed the 'Overall Index of Pollution' (OIP) for Indian rivers based on measurements of $\mathrm{pH}$, turbidity, dissolved oxygen, BOD, hardness, total dissolved solids, total coliforms, arsenic and fluoride. Each water quality observation was scored as Excellent, Acceptable, Slightly polluted, Polluted and Heavily polluted according to the Indian standards/ guidelines and standards of WHO. After categorization, each observation was assigned a pollution index value. The 'Overall Index of Pollution' (OIP) is calculated as the average of each index value given by the following mathematical expression:

$$
\mathrm{OIP}=\sum_{i=1}^{n} P i / n
$$

Where $\mathrm{Pi}=$ pollution index for ith parameter, $\mathrm{n}=$ number of parameters

To recognize a unique WQI for assessing surface water quality of a particular area or country with a definite solution is very difficult (Bharti and Katyal 2011). However, The NSFWQI seems to be one of the most comprehensive forms of WQI based on expert opinion whereas OIP has been developed in the context of Indian conditions. These two methods i.e. OIP and NSFWQI have been used for estimating the WQI of Sukhna lake water. Water quality of the lake is found in 'acceptable' range using the OIP method as given in Table 1.

The NSFWQI used for estimating the quality of Sukhna lake water is mathematically expressed as follows:

$$
W Q I=\sum_{i=1}^{n} W_{i} Q_{i}
$$

where $Q_{i}=$ Sub index for ith water quality parameter $\mathrm{W}_{\mathrm{i}}=$ Weight (in terms of importance) associated with water quality parameter

$\mathrm{n}=$ Number of water quality parameters

NSFWQI has been calculated using the standard software (Oram 2012) and the results are reported in Table 1 and graphically shown in Figure 2. It can be seen that the lake water quality is found to be in the 'good' quality range during 2006-12. The water quality is found suitable for bathing purpose with designated best use of outdoor bathing (CPCB 2008) as the DO is found $>5 \mathrm{mg} / \mathrm{l}, \mathrm{BOD}<3 \mathrm{mg} / \mathrm{l}$ and $\mathrm{pH}$ between 6.5 to 8.5 during the measurement period. The water quality is also suitable for supporting the fish population in the lake and for migratory birds as well.

The U.S. Environmental Protection Agency (USEPA) has specified a turbidity limit of 5 NTU for any lake to be used for swimming and recreational purposes (EPA 2006) but the Sukhna Lake fails on this account as the turbidity is rather high (Table 1) but no standards are provided by the Government of India on the turbidity limit acceptable for swimming and recreational purposes. 


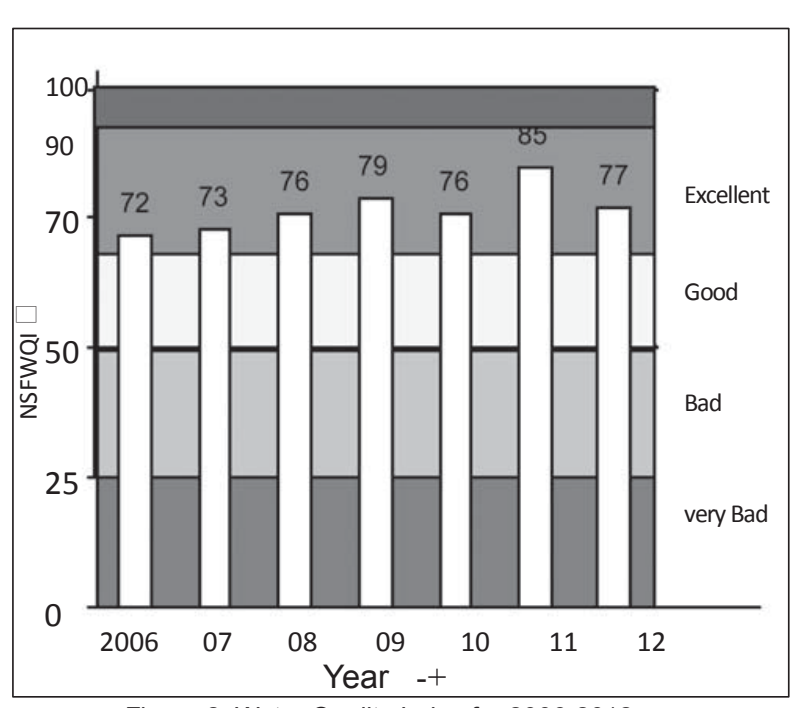

Figure 2. Water Quality Index for 2006-2012.

The reasons for the high turbidity and corrective steps taken by the Chandigarh administration to control this parameter are discussed in the next section.

\section{Results and Discussion}

Soil erosion by water is the most serious land degradation problem worldwide (Eswaran, Lal and Reich 2001). It affects not only the agricultural production and other infrastructure but water quality also (Lal 1998; Pimentel, Harvey et al 1995). As is evident from the above water quality data, turbidity is found as the main stressor in the Sukhna Lake due to receiving of silt and dissolved minerals from the catchment. Since the creation of the lake in 1958 up to 1988 , the rate of siltation in the lake was more than $150 \mathrm{t} / \mathrm{ha} /$ year. It is due to the prevailing edaphic and biotic factors in the Shivalik hills, the youngest of all mountains in India, which are ecologically sensitive and geologically very unstable and so highly prone to soil erosion during rains. More than one-third of the catchment area of the watershed of the lake falls in 'high to very high erosion' category due to steep hill slopes, which are prone to more soil and water erosion (Shrimali 1999; Shrimali et al 2001). Though the catchment treatment of such slopes is difficult in terms of establishment of vegetation, the Department of Forest and Wildlife, Chandigarh administration has considerably succeeded in greening most of the catchment area falling in the sanctuary during the last eight years. The preventive measures (vegetative and engineering) were undertaken by the Chandigarh administration in the forest area falling mainly in the hilly portion of the catchment. Massive plantations were undertaken in the Kansal and Nepli reserved forests of the catchment, which were declared as the "Sukhna Wild Life Sanctuary" in 1977. Engineering structures like check dams, silt retention dams, mechanical spurs, and revetments were also created. All these measures have reduced the rate of siltation to around 5-6 t/ha/yr during last few years (Sohal 2000; SPACE 2008), and this is the main reason for maintaining the water quality as 'good' during 2006-2012 as shown in Figure 2. It is observed that, broadly, the water quality is improving from 2006 onwards except in 2010 and 2012. Turbidity is declining during 2011 and 2012 in comparison to earlier years (Table 1) but increase in BOD and Total Phosphorus (TP) level in 2012 is a matter of concern and responsible for the resultant decline in the water quality index from 85 (in 2011) to 77 (in 2012). Sewage and waste water from cattle and poultry sheds from the catchment villages seem to be the main reason for this decline.

As stated elsewhere, about $20 \%$ of the lake catchment area is in the plains which include villages located in UT Chandigarh and Punjab. These villages are Kaimbwala, Khuda Alisher and Kansal. Untreated sewage and other domestic wastes like run offs from cattle sheds of the villages find their way to the lake during the rainy season. The lake is likely to become rich in nutrients $\mathrm{N}, \mathrm{P}$ and $\mathrm{K}$ etc that have led to the growth of aquatic weeds during the last 3-4 years and have comparatively higher evapotranspiration rate of water in comparison to other plants, causing rapid loss of lake water during summer season. The National Botanical Research Institute (NBRI), Lucknow, India has identified the following weeds in the lake: Hydrilla verticillata, Vallisneria spiralis, Typha species, Potamogeton crispus, and Zannichellia palustris.

The charm of living near the lake and the capital city of Chandigarh has led to rapid urbanization of the catchment area, especially, in the Kansal village of Punjab. During the survey, it was found that agricultural land was being sold in the village at prices between IRs. 40-50 million/acre. In 2011, a multistoried Tata Group housing project was initiated in this part of the catchment area due to political and other influences. Recently, the Punjab and Haryana High Court has stopped all sort of construction activities in the catchment and has asked the Chandigarh administration, Punjab and Haryana governments to publicize the boundaries of the catchment area in local newspapers to prevent any new construction. There is, therefore, a need for proper coordination among the States of Punjab, Haryana and U.T of Chandigarh to conserve the lake, which is lacking at present, as observed by the Punjab and Haryana High Court at times. To protect the lake, soil conservation and plantation activities in the catchment area need to be strengthened in terms of regular maintenance and desilting of 190 silt detention dams. In addition, providing sewage treatment plant facility and safe disposal of solid wastes in the catchment area should be taken up immediately.

\section{Conclusion}

The Sukhna Lake is known as a famous spot for outdoor recreation and tourism in north India. The Chandigarh administration is spending a significant portion of the annual budget on its maintenance and upkeep. Construction activities in the catchment have increased 
during last few years and due to inflow of untreated sewage from nearby villages, mainly during the rainy season, invasive alien species of weeds have come up in the lake. Setting up a sewage treatment plant or diversion of waste water away from the lake in nearby villages and imposing a ban on new construction in the catchment area is a must for maintaining the good health of the water body along with regular de-weeding and silt removal. All the above measures would help not only in improving the water quality but also increasing the recreational and aesthetic value of the Sukhna Lake.

\section{Acknowledgements}

One of the authors (P. Chaudhry) would like to express gratitude to the National River Conservation Directorate (NRCD), Ministry of Environment and Forests, Government of India, New Delhi for providing the financial assistance in the form of sponsorship for the M. Tech programme in Environmental Management of Rivers and Lakes (2011-13) being offered by the Alternate Hydro Energy Centre, Indian Institute of Technology, Roorkee, India.

M.P. Sharma, Ph.D., has been working as Associate Professor at Alternate Hydro Energy Center, Indian Institute of Technology, Roorkee (India), since the last 25 years. His area of research are renewable energy with special reference to bio-diesel production and utilization, Modeling of IRES, Hybrid Energy Systems, induction generators, EIA of renewable energy projects, Energy and Environment conservation, conservation of water bodies, water quality assessment and GHG emissions from reservoirs and lakes.

Corresponding address: mpshafah@iitr.ernet.in

Pradeep Chaudhry is working as Chief Conservator of Forests in Arunachal Pradesh, India. Currently he is undergoing two years Masters of Technology Degree in 'Environmental Management of Rivers and Lakes' (2011-13) as a sponsored candidate at Alternate Hydro Energy Centre, Indian Institute of Technology Roorkee, India. His research interests include valuation of natural resources, urban forestry, biodiversity conservation and water quality assessment.

P. J. S. Dadhwal is presently working as Member Secretary of Chandigarh Pollution Control Committee and also responsible for the work of Department of Environment and Science \& Technology of Chandigarh administration as Additional Director. He has number of research papers to his credit and authored one book 5oth year of Independeence-Environment in India.

Renu Bhargava, Ph.D. in a career spanning over 40 years, has been with Uttar Pradesh Irrigation Department and IIT Roorkee, India (formerly University of Roorkee). Currently she is working as Professor in Civil Engineering department at IIT Roorkee, where she has guided many PhDs and M.Tech students. Over the last 30 years, she has authored over 50 research papers. Her areas of expertise include solid waste management and water treatment, industrial waste management, advance water supply and sewerage. She has visited many countries including U.S.A. Czech Republic, Austria and had been keynote speakers at various forums, in national and international conferences. She is a fellow of Institution of Engineers (India), Indian Water Works Association, Institution of Public Health Engineers (India), Indian Association of Hydrologists and Member of International Water Association, International Solid Waste Association, Indian Association for Environmental Management.

\section{References}

Abbasi, S. A., 2002, Water quality indices, State of art report, National Institute of Hydrology. Scientific contribution no. INCOH/SAR-25/2002, Roorkee, pp 73.

APHA, 1989, American Public Health Association. Standard methods for the examination of water and waste water, 17 th edition.

Bharti, N. and D. Katyal, 2011, Water quality indices used for surface water vulnerability assessment, International Journal of Environmental Sciences, 2(1): 154-173.

Brown, R. M., N. I. McClelland, R. A. Deininger and R. G., Tozer, 1970, A water quality Index-Do we dare? Water Sewage works, 117(10): 339-343.

Chaudhry, P., B. Singh and V. P., Tewari, 2007, Non-market economic valuation in developing countries: Role of participant observation method in CVM analysis, Journal of Forest Economics, 13(4): 259-275.

Costanza, R., R., d'Arge., R. de Groot., S. Farbe, M.Grasso, K. Limburg, B. Hannon, S. Naeem, R.V. O’Neill, R.G. Raskin, P. Sutton and Belt. M. Vanden, 1997, The value of the world's ecosystem services and natural capital, Nature, 387: 253-260.

CPCB, 2008, Guidelines for Water Quality Monitoring, issued by Central Pollution Control Board, N. Delhi vide MINARS/27/2007-08.

Debels, P., R. Figueroa, R. Urrutia, R. Barra and X. Niell, 2005, Evaluation of water quality in the Chilla river of Central Chile using physicochemical parameters and a modified water quality index, Environmental Monitoring and Assessment,110: 301-322.

EPA, 2006, Framework for developing suspended and bedded sediment water quality criteria. United States Environmental Protection Agency, Washington D.C, EPA/822-R-06-001.

Eswaran, H., R. Lal, and P.F. Reich, 2001, Land degradation: A review. In E.M Bridges, I.D. Hannam, L.R Oldeman, F W T Penning de vries, S .J Scherr, S Sombatpanit (Eds); Response to Land degradation, Science Publishers Inc, Enfield, USA ,2001: 20-35.

Gopal, B., M. Sengupta, R. Dalwani and S.K. Srivastava, 2010, Conservation and Management of lakes- an Indian perspective. A Ministry of Environment and 
Forests, National River Conservation Directorate, Paryavaran Bhavan, New Delhi publication.

Grewal, S.S. and M.L. Juneja, 1984, Studies on erosional behavior of the soil in the catchment of a rapidly silting lake at Chandigarh, Journal of soil conservation, 12(1): 58-65.

Horton, R.K., 1965, An index number for rating water quality, Journal of Water Pollution Control Federation, 37(3): 300-306.

Jain, S.M., M. Sharma and R. Thakur, 1996, Seasonal variations in physicochemical parameters of Halai reservoir of Vidisha district, India, Indian Journal of Ecobiology, 8(3): 181-188.

Kannel, P.R., S. Lee, Y. S. Lee, S.R. Kanel and S. P. Khan, 2007, Application of water quality indices and dissolved oxygen as indicators for river water classification and urban impact assessment, Environmental Monitoring and Assessment, 132: 93-110.

Lal, R., 1998, Soil erosion impact on agronomic productivity and environmental quality, Critical Reviews in Plant Sciences, 17(4): 319-469.

Lumb, A., D. Halliwell and T. Sharma, 2002, Canadian water quality index to monitor the changes in water quality in the Mackenzie River-Great Bear. In: Proceedings of the 29th Annual aquatic toxicity workshop, Oct 21-23, Whistlar, B.C, Canada.

Mahesha and Balasubramanian, 2010, Analysis of water quality index (WQI) in Dalvoy Lake, Mysore city, India, Nature Environment and Pollution Technology, 9(4): 663-670.

Moundiotiya, C., R. Sisodia, M. Kulshreshtha and A. L. Bhatia, 2004, A Case Study of Jamwa Ramgarh wetland with special reference to physicochemical properties of water and its environs, Journal of Environmental Hydrology, 12(24): 1-7.

Oram, B., 2012, Monitoring the quality of surface water. At www.water-research.net/watrqualindex/index. htm., accessed on Aug, 11, 2012.

Padmanabha, B. and S.L. Belagali, 2005, Comparative study on the water quality index of four lakes in the Mysore city, Indian journal of Environmental Protection, 25(10): 873-876.

Pimentel, D., C. Harvey, P. Resosudarmo, K. Sinclair, D. Kurz, M. McNair, C. Crist, L. Shpritz, L. Fitton, R. Saffouri and R. Blair, 1995, Environmental and economic costs of soil erosion and conservation benefits, Science, 267(2): 1117-1123.

Sargaonkar, A. and V. Deshpande, 2003, Development of an overall index of pollution for surface water based on a general classification scheme in Indian context, Environmental Monitoring and Assessment, 89: 43-67.

Shastri, Y. and D.C. Pendse, 2001, Hydrobiological study of Dahikhura reservoir, Journal of Environmental Biology, 22(1): 67-70.

Shrimali, S. S., 1999, Rainfall-run off modeling using remote sensing and GIS - A case study of Sukhna lake catchment. Published by Centre for space science and technology education in Asia and Pacific, IRS Campus 4, Kalidas road, Dehradun, India

Sisodia, R. and C. Moundiotiya, 2006, Assessment of water quality index of wetland Kalakho lake, Rajasthan, India, Journal of Environmental Hydrology, 14(23): 1-11.

Society for promotion and conservation of environment (SPACE), 2008, Study on Impact of soil conservation measures in the catchment of Sukhna Lake on ground water, soil and geology, A report submitted to the Chandigarh administration in March, 2009.

Sohal, H.S., 2000, Soil and water conservation measures for sediment control in Sukhna Lake, Chandigarh. In Mittal, S.P, Agarwal, R.K, Samra, J.S (Editors). Fifty years of research on sustainable resource management in Shivaliks. A publication of Central soil and water conservation research and training institute, Chandigarh, pp. 259-266.

Sreenivasan, A., P.K. Venkatanarasimha and T. Franklin, 1997, Limnological study of a shallow water body (Kolovoi Lake) in Tamil Nadu, India, Journal of Indian Hydrobiology, 2(2): 61-69.

Srinivasa, G. S. and B. Kotaiah, 2000, Seasonal variation of water quality in tropical Kalyani reservoirs, near Tirupati, Indian Journal of Environmental Protection, 20(6): 452-455.

Thorat, S.R. and S. Masaraat, 2000, Pollution status of Salim Ali Lake, Aurangabad, India, Journal of Pollution Research, 19(2): 307-309.

Wattas, R. and D. Gandhi, 2009, Sukhna-Sublime Lake of Chandigarh. Book by Rupa and Company, New Delhi and Department of Tourism, Chandigarh Administration, Chandigarh.

\section{CALENDAR OF EVENTS - IRRIGATION}

19-20 February, 2013: Landscape Irrigation Auditor Course. Location: Denver, Colo. Contact Email: trainingservices@rainbird.com. More info: http://www.irrigation.org/calendar. aspx?calid $=175 \&$ id $=496$

11-12 March, 2013: Irrigation Contractor Course - Chicago, Ill. Contact Email: trainingservices@ rainbird.com. More info: http://www.irrigation.org/ calendar.aspx? calid $=175 \& i d=496$

29-30 May, 2013: IAL (Irrigation Australia) Conference. Location: Griffith, NSW. Theme for the conference is "Better knowledge sharing for better irrigation outcomes". More info: http:// www.irrigation.org.au/index.cfm?/events/2013conference

29 September-3 October, 2013: First World Irrigation Forum (WIF). Location: Mardin, Turkey. More info: http://www.icid.org/wif/

14-20 September, 2014: 22nd International Congress on Irrigation and Drainage. location: Gwangju Metropolitan City, Republic of Korea. More info: http://www.icid2014.org 